\title{
Effect of Communication Competence on Self-Efficacy in Kaohsiung Elementary School Directors: Emotional Intelligence as a Moderator Variable
}

\author{
Cheng-Ping Chang1, Chiung Wen $\mathrm{Hu}^{2}$ \\ ${ }^{1}$ Department of Education, National University of Tainan, Taiwan \\ ${ }^{2}$ Graduate Institute of School Entrepreneurship and Management, College of Education, National Tainan University, Taiwan \\ Email: justin23@mail.nutn.edu.tw, hihipi@yahoo.com
}

How to cite this paper: Chang, C. P., \& Hu, C. W. (2017). Effect of Communication Competence on Self-Efficacy in Kaohsiung Elementary School Directors: Emotional Intelligence as a Moderator Variable. Creative Education, 8, 549-563.

https://doi.org/10.4236/ce.2017.84043

Received: March 8, 2017

Accepted: April 21, 2017

Published: April 27, 2017

Copyright ( 2017 by authors and Scientific Research Publishing Inc. This work is licensed under the Creative Commons Attribution International License (CC BY 4.0).

http://creativecommons.org/licenses/by/4.0/

\begin{abstract}
Modern schools are faced with enormous pressure and require educators to constantly grow professionally in response to various social changes. Thus, in the light of current challenges, this study examined the self-efficacy of elementary school directors. The relationships between and influences on communication competence, emotional intelligence (EI), and self-efficacy were investigated through the example of Kaohsiung elementary school directors, and the moderating effect of EI on the relationship between communication competence and self-efficacy was tested. This study employed a questionnaire survey through which an effective sample of 272 Kaohsiung elementary school directors was obtained. Research tools included Spitzberg and Cupach's (1989) interpersonal communication competence scale, Tschannen-Moran and Gareis's (2004) principal sense of efficacy scale, and Wong and Law's (2002) EI scale. Data was analyzed using SPSS statistical software. The results indicated 1) a significant positive effect of communication competence on self-efficacy; 2) a significant positive effect of EI on self-efficacy; and 3) a moderating effect of EI on the relationship between communication competence and self-efficacy.
\end{abstract}

\section{Keywords}

Communication Competence, Self-Efficacy, Elementary School Directors, Emotional Intelligence

\section{Introduction}

As countries reform their education systems to adapt them to the needs of mod- 
ern society, school leaders become increasingly important with regard to educational policy issues (Pont, Nusche, \& Moorman, 2008). Generally, school matters are handled through a school director's leadership and management. However, under the influence of contemporary changes, many schools apply an empowering distributed leadership style, which fosters autonomous decision-making and responsibility for outcomes among directors. According to Bandura (1997), challenges can form more evident self-efficacy and illustrate its added value. Efficacy in cognitive and emotional processes has similarities with models of human nature and operations. Bandura (1986) believed that self-efficacy operations can affect people's motivations and actions and supported a conceptual framework in which human behavior was emphasized as influenced by conscious and unconscious psychological factors.

Many scholars mention the ability of language to help in self-development. Semin (n.d.) pointed out that human cognition is a result of successful interaction with other individuals and the external world. Mead (1934) maintained that individuals can transfer ideas and grow spiritually when using verbal and nonverbal signs and symbols. According to Potter and Edwards (2001), situated, action-oriented, and constructed discourse can help people specify their inner beliefs, system of values, feelings, and attitudes and explain their actions. Moreover, Carnegie (1936), a famous US specialist on human relations, proposed nine rules for human relations and related training methods; he taught human relations and communicative competence in operations to help people increase their popularity and their influence, thus increasing their self-efficacy.

Communication is the basis of organizational operations. Tariszka-Semegine (n.d.) suggested that even low-ranking staff must possess communication skills, which are especially important on the managerial level. Effective communication can improve organizational productivity, thus fostering organizational growth. Boroon (2013) discussed the communication skills of oil company managers and stated that effective communication between managers and staff and understanding the motivations of the other party are factors that can help a company achieve its targets. There is a close relationship between successful leadership and communication competence. Leaders with good communication competence often benefit from high emotional intelligence (EI). Many scholars have indicated a positive relationship between communication competence and EI (e.g. Moradi-Dasht \& Noorbakhsh, 2014; Jorfi, Jorfi, Yaccob, \& Nor, 2014; Marzuki, Mua, \& Saad, 2015). Recent research has found that EI has a predictive power for self-efficacy and achievements at work, influencing individual productivity, satisfaction, well-being, and social atmosphere (e.g. Abdolvahabi, Bagheri, \& Kioumarsi, 2012; Nikoopour, Farsani, Tajbakhsh, \& Kiyaie, 2012; Sarkhosh, \& Rezaee, 2014). Thus, EI can suggest a direction of how to improve communication competence and significantly affects self-efficacy.

Self-efficacy is a basic characteristic of a successful leader (Tschannen-Moran \& Gareis, 2004). The position of a school director is a leadership position. Therefore, this study examined self-efficacy among Kaohsiung elementary school di- 
rectors and discussed effective strategies for its improvement. Bandura (1977) suggested that there are four sources of self-efficacy, namely, mastery experience, psychological arousal, vicarious experience, and verbal persuasion. This study aimed to verify whether communication competence and work-related EI influence self-efficacy. Furthermore, this study was the first to use EI as a moderator variable to analyze the relationships between EI, communication competence, and self-efficacy. It also investigated how EI fosters the development of a leader's self-efficacy through its influence on such important aspects as negotiation, leadership, trust, and work performance. In sum, the objectives of this study were as follows:

1) To explore the current levels of communication competence, self-efficacy, and EI among Kaohsiung elementary school directors.

2) To investigate the effect of the communication competence and EI of Kaohsiung elementary school directors on their self-efficacy.

3) To investigate a moderating effect of EI on the relationship between communication competence and self-efficacy among Kaohsiung elementary school directors.

\section{Literature Review}

The following is a review of research related to the relationship between the three main variables examined in this study.

\subsection{Communication Competence}

The definition of "communication" varies across communication-related studies and constantly changes. The main objective of any communicative activity is to communicate meaning. According to the communication process model proposed by Schramm (1971), the coding and decoding of the meaning contained in each message are the two major factors of effective communication, the absence of which makes it difficult for two parties to exchange information. The cooperative principle proposed by Grice (1975) describes four rational principles of effective communication: 1) the maxim of quantity, 2) the maxim of quality, 3) the maxim of relation, and 4) the maxim of manner. According to Austin (1962: p. 120), a speech act includes three levels and a meaningful utterance comprises: 1) a locutionary act, 2) an illocutionary act, and 3) a perlocutionary act. Spitzberg and Cupach's $(1984,1989)$ relationship model focused on listener expectations and opinions. According to the model, meaning emerges during a communicative activity combining three individual factors, namely, knowledge, skills, and motivation, as well as situational factors, such as the model of interaction, standards and principles, the model of relationship, the field, and the activity.

Many communication competence assessment tools are based on Spitzberg and Cupach's $(1984,1989)$ theory. Such scales of interpersonal communication competence have been proven to be reliable and effective. For instance, Payne (2005) developed a scale based on three dimensions proposed by Spitzber and Cupach, namely, skills, motivation, and knowledge. The scale evaluated an indi- 
vidual's reactions to situations and could determine the difference in the communication competence of different leaders while also considering individual needs and situational cultural factors. Being applicable to social interactions and the organizational field, the scale was used in this study.

\subsection{Self-Efficacy}

Using the perspective of social learning, Bandura (1977) proposed the self-efficacy theory, in which self-efficacy refers to one's beliefs about his or her ability to achieve goals through certain actions. Self-efficacy can affect psychological state, behavior, and motivation. In addition, efficacy beliefs determine how much effort a person will spend and how long he or she will persist when faced with a disappointment or difficulty (Bandura, 1993). Such mechanisms of for the influence of efficacy explain how a person manages to find ways to continue operations and maintain control in a challenging environment.

With the popularization of cognitive psychology, scholars have begun to give consideration to the influence of educators' internal cognitive processes on their behavior and have suggested that the latter is related to pre- and post-activity thinking. As a result, research on self-efficacy beliefs was extended to the fields of teacher efficacy, collective efficacy, and leadership efficacy (e.g. Goddard, Hoy, \& Woolfolk, 2000; Tschannen-Moran \& Woolfolk, 2001; McCormick, Tanguma, \& Lopez-Forment, 2002). Ashton (1984) named two dimensions of teacher efficacy, general and personal. General efficacy refers to the extent to which a teacher believes his or her students can learn the material, whereas personal efficacy is the extent to which a teacher believes his or her students can learn under the teacher's guidance. Teacher efficacy beliefs belong to the relational system of self-beliefs. These beliefs constitute the teachers' global and specific judgments about themselves in the classroom context (Silverman \& Davis, 2009). Leadership efficacy considers the positive psychological abilities, motivation, methods, collective resources, and behaviors required for achieving effective and sustainable outcomes under different leader roles, requirements, and circumstances. According to Hannah, Avolio, Luthans, and Harms (2008: p. 1), leadership efficacy is a "specific form of efficacy associated with the level of confidence in the knowledge, skills, and abilities associated with leading others." Collective efficacy can be defined as a "group's shared belief in its conjoint capabilities to organize and execute the courses of action required to produce given levels of attainments" (Bandura, 1997: p. 477). Within a group, collective efficacy represents group members' beliefs about "the performance capacity of the social system as a whole" (Bandura, 1997: p. 469), that is, beliefs about the group's ability to assist in actions and group performance.

Self-efficacy scales contain constructs related to groups, leaders, and followers. This study used Tschannen-Moran and Gareis's (2004) principal sense of efficacy scale to examine self-efficacy in elementary school directors. School directors' work is more complicated than that of teachers as they bear the important responsibility of administrating a school under the conditions of current educa- 
tional reforms. The scale evaluates skills required to be a leader. In addition to being based on a clear theoretical framework and showing good reliability and effectiveness, the scale is also appropriate for the participants in this study.

\subsection{Emotional Intelligence (EI)}

A formal theory of EI originated with Salovey and Mayer's (1990) conceptual framework in which EI was defined as the ability to differentiate and monitor one's own and others' emotions and use this information to guide one's thinking and behavior. In 1997, Salovey and Mayer further clarified EI as the ability to accurately perceive, assess, and express emotions; use and generate emotional knowledge; and regulate emotions in order to promote emotional and intellectual growth. The term EI was popularized and received wide attention after the publication of Goleman's (1995) non-academic monograph about EI. Goleman defined EI as the ability to realize one's own feelings, control impulses and anger, and maintain a calm and optimistic attitude when faced with difficulties. In "Working with Emotional Intelligence, II," Goleman (1998) further investigated the framework of EI as a basic capacity and distinguished between personal ability and social ability, which determines how one interacts with others. Personal ability involves self-awareness, self-regulation, and motivation. Social ability involves empathy and interpersonal skills. Among other well-known scholars, Bar-on (1997) suggested that EI affects emotional, personal, and interpersonal abilities to cope with environmental demands and pressures. According to Bar-on, EI is an important factor that determines one's success in life and has a direct influence on overall psychological health. Bar-on proposed that emotional and social intelligence consists of five major elements, which are intrapersonal skills, interpersonal skills, adaptability, stress management, and general mood.

An emotional intelligence scale can be divided into two dimensions, namely, ability EI and trait EI (Petrides \& Furnham, 2000). This study employed the Wong and Law Emotional Intelligence Scale (WLEIS, Wong \& Law, 2002) for specific emotions. Specifically designed for organizational research and involving an EI self-report scale consisting of 16 items, the WLEIS allows fast and appropriate measurement of EI. Moreover, the WLEIS has a good reliability ( $\alpha$ $=.70-.85)$ and content related to measuring EI at the workplace and job satisfaction, thus meeting the needs of this study.

\subsection{Related Research and Hypothetical Deductions Regarding Relationships between the Variables}

1) Discussion and hypothetical deductions regarding the effect of communication competence on self-efficacy

Communication is a process of bidirectional interaction that requires the ability to use necessary skills under a certain situation in order to share the message meaning successfully. In communication, the language structure influences nonlanguage sections, memory, perception, attention, and thinking. Vygotsky (1978) 
observed the development of planning abilities in children through language activities and maintained that children used language to plan problem solutions and implemented prepared solutions throughout activities. He concluded that higher order thinking was due to inner speech, i.e., internalized language symbols. Semin (n.d.) considered language as a tool to implement cognition that has a function of representing subjects according to the subject-body relationships and actions they need to perform.

Based on the above, this study proposed Hypothesis 1: Communication competence of elementary school directors significantly and positively affects their self-efficacy.

2) Discussion and hypothetical deductions regarding the effect of EI on selfefficacy

The relationship between emotion and cognition has been the subject of wide discussion in psychology of emotions since the 1960s. Under the influence of cognitive psychology, Mandler (1980) suggested that it is necessary to establish a psychological theory of emotions and focus research on automatic emotional responses and their mechanisms in order to gain a better understanding of memory span, recollection process, and attention. Lazarus and Folkman (1984) proposed the theory of an individual's coping with and the following cognitive appraisal of environmental stresses. Salovey and Mayer (1997) defined EI on a cognitive basis. In a sense, EI resembles the self-regulatory mechanism within social intelligence described by Bandura. Moreover, Bandura (1977) determined emotional arousal to be a source of self-efficacy that, thus, can be improved by regulating one's psychological state. This shows a close relationship between EI and self-efficacy.

Based on the above, this study proposed Hypothesis 2: EI of elementary school directors significantly and positively affects their self-efficacy.

3) Discussion and research related to the moderating effect of EI on the relationship between communication competence and self-efficacy

Charles Darwin was the first to suggest that non-verbal symbols, such as facial expressions and gestures, are a result of emotions. Drawing from the theory of evolution, Stearns and Stearns (1994) also stated that emotions had a communication function prior to language. Recent theories of EI have found that such EI features as adaptability, empathy, and intimacy toward the surrounding people, events, and objects help to regulate one's emotions and use them in different situations. Moreover, many EI measurement tools integrate interpersonal communication into the content evaluating EI. For instance, a measurement tool proposed by Mayer, Salovey, and Caruso (2002) can reflect verbal and cognitive skills used to manage emotional information and help to learn about culture and customs. As pointed out by Engelberg and Sjoberg (2005), emotions can be absorbed from others; people can have a subjective emotional experience through automatically imitating and integrating others' facial expressions, voice, gestures, and movements. Interaction participants who share very similar EI better understand each other's intentions and reasons and make appropriate adjust- 
ments.

Based on the above, this study proposed Hypothesis 3: EI has a significant moderating effect on the relationship between communication competence and self-efficacy in elementary school directors.

\section{Method}

Based on the research questions, the following hypotheses were proposed in this study:

H1: The communication competence of elementary school directors significantly and positively affects their self-efficacy.

H2: The EI of elementary school directors significantly and positively affects their self-efficacy.

H3: EI has a significant moderating effect on the relationship between communication competence and self-efficacy in elementary school directors.

The research framework is presented next, including participants, sampling method, research tools, and their reliability.

\subsection{Participants and Sampling Method}

Participants in this study were directors from private elementary schools in Kaohsiung employed in 2015. This study evaluated the influence of their communication competence on self-efficacy, as well as the moderating effect of EI on such influence. This study employed a questionnaire survey as a sampling method.

\subsection{Research Tools}

1) Communication competence

The operational definition of communication competence in this study was the elementary school directors' perceived levels of interpersonal communication motivation, communication knowledge, and communication skills according to the communication competence scale employed in the study.

The scale was developed referring to Spitzberg and Cupach's (1984) interpersonal communication competence scale. The scale included 17 items and used a 5 -point Likert scale, with higher scores indicating a better performance in interpersonal communication competence.

2) Self-efficacy

The operational definition of self-efficacy in this study was the elementary school directors' perceived levels of administrative efficacy, instructional leadership, and moral leadership according to the sense of efficacy scale employed in the study. The scale was developed referring to Tschannen-Moran and Gareis's (2004) principal sense of efficacy scale. The scale included 15 items and used a 5-point Likert scale, with higher scores indicating better self-efficacy.

(3) EI

The operational definition of EI in this study was the elementary school directors' perceived levels of self-emotional appraisal, others' emotional appraisal, 
emotional regulation, and the use of emotions according to the EI scale employed in the study. The scale was developed with reference to the WLEIS. The scale included 11 items and used a 5-point Likert scale, with higher scores indicating a higher degree of EI.

\subsection{Validity and Reliability of Research Tools}

1) Content validity

After preliminary translation of the original scales, English language teachers, scholars specializing in the related domain, and field practice experts were invited to examine content validity of the scales in terms of their accuracy, item clarity, and relevance. The following adjustments were made by experts to ensure content validity: 13 items were revised and 1 was deleted in the communication competence scale, 7 items were revised and 3 were deleted in the self-efficacy scale, and 2 items were revised and 5 were deleted in the EI scale.

2) Factor analysis

After the adjustments made by experts to ensure content validity of the scales, a pre-test questionnaire was compiled from the remaining items. On February $26,2016,89$ questionnaires were administered to conduct a pre-test and 75 were returned. After excluding 6 invalid responses, 69 valid responses were obtained, yielding the effective response rate of $77.8 \%$. Construct validity of the scales was evaluated through factor analysis of pre-test results. Factor analysis results showed that each item had a factor loading of 0.6 or higher. One common factor was extracted for each level; thus, all items within a level remained unchanged.

3) Reliability analysis

Reliability analysis results showed that the Cronbach's a values were .967 for the communication competence construct, .956 for the self-efficacy construct, and .928 for the EI construct; thus, the Cronbach's a for each construct was equal to or over .7. Furthermore, the Cronbach's a for the overall scale was .981. As a high reliability was achieved, the official questionnaire was administered to participants.

\section{Results and Discussion}

\section{Data Analysis}

The official questionnaire was administered on March 26, 2016, and responses were collected before April 19, 2016. 355 questionnaires were administered, with 289 returned. After the elimination of 17 invalid returned questionnaires, the effective sample included 272 responses, yielding an effective response rate of $77 \%$. The following section explains the findings for each variable and the results of the regression analysis.

1) Findings for main variables

The average total score in communication competence was 4.03, which indicated a high degree of competence according to the 5-point Likert scale. Among the average total scores in different constructs, the highest was observed in communication motivation (4.11), followed by communication knowledge (4.02). 
The lowest average total score was obtained in communication skills (3.95). Thus, an above moderate average score was achieved in all constructs. With regard to self-efficacy, the average total score reached an above moderate level of 3.90. Among its constructs, the highest average total score was obtained in administrative efficacy (4.04), followed by moral leadership efficacy (3.83), and the lowest score was obtained in instructional leadership efficacy (3.80). Participants' average total score in EI was 3.95, reaching an above moderate level. Among EI constructs, the highest average total score was obtained in self-emotional appraisal (4.06), followed by the use of emotions (4.01) and emotional regulation (3.94), and the lowest score was obtained in others' emotional appraisal (3.87).

2) Regression analysis

A regression analysis of communication competence, EI, and self-efficacy in order to verify pairwise correlations was conducted. As shown in Table 1, the standardized $\beta$ coefficient for the effect of communication competence on selfefficacy was .743 and the p-value was 0.000 . Thus, $\mathrm{H} 1$ was supported: the communication competence of elementary school directors significantly and positively affected their self-efficacy. The standardized $\beta$ coefficient for the effect of EI on self-efficacy was .770 and the p-value was 0.000 . Thus, H2 was supported: the EI of elementary school directors significantly and positively affected their self-efficacy.

With regard to the influence of different constructs within communication competence (Table 2), including communication motivation, communication knowledge, and communication skills, all of them had a significant effect on the self-efficacy of elementary school directors $(p=0.000)$. Among the constructs, communication skills $(\beta=.745)$ showed the strongest influence and communication motivation $(\beta=.710)$ showed the weakest influence. In EI, all four constructs had a significant effect on the self-efficacy of elementary school directors $(p=0.000)$. The use of emotions $(\beta=.732)$ showed the strongest influence and others' emotional appraisal $(\beta=.607)$ showed the weakest influence.

3) Hierarchical regression analysis

A hierarchical regression analysis was conducted to evaluate the effect of communication competence and EI on the self-efficacy of elementary school directors. Results indicated (Table 3 ) an interaction between communication competence and EI $(\beta=.483 ; \mathrm{p}=.000)$ and their significant and positive effect on self-efficacy. Thus, H3 was confirmed: EI had a significant moderating effect on the relationship between communication competence and self-efficacy in elementary school directors.

4) General discussion

a) Verification of the effect of communication competence on self-efficacy

In this study, school directors' communication competence was found to have a significant and positive effect on their self-efficacy, meaning that better communication competence was associated with higher self-efficacy. With regard to the influence of communication competence constructs on self-efficacy, communication skills had the highest effect, whereas communication motivation had 
Table 1. Regression analysis of the effect of communication competence and EI on selfefficacy.

\begin{tabular}{cccccccc}
\hline $\begin{array}{c}\text { Criterion } \\
\text { variable }\end{array}$ & $\begin{array}{c}\text { Predictor } \\
\text { variable }\end{array}$ & B & $\begin{array}{c}\text { Standard } \\
\text { error }\end{array}$ & $\beta$ coefficient & t value & VIF & p value \\
\hline Self-efficacy & $\begin{array}{c}\text { Communication } \\
\text { competence }\end{array}$ & .834 & .046 & .743 & 18.225 & 1.000 & $.000^{* * *}$ \\
EI & .807 & .041 & .770 & 19.819 & 1.000 & $.000^{* * *}$ \\
\hline
\end{tabular}

${ }^{* * *} \mathrm{p}<.001$.

Table 2. Regression analysis of the effect of communication competence and EI constructs on self-efficacy.

\begin{tabular}{|c|c|c|c|c|c|c|}
\hline $\begin{array}{l}\text { Criterion } \\
\text { variable }\end{array}$ & Predictor variable & B & $\begin{array}{l}\text { Standard } \\
\text { error }\end{array}$ & $\begin{array}{c}\beta \\
\text { coefficient }\end{array}$ & $\mathrm{t}$ value & $\mathrm{p}$ value \\
\hline \multirow[t]{7}{*}{ Self-efficacy } & $\begin{array}{l}\text { Communication } \\
\text { motivation }\end{array}$ & .769 & .046 & .710 & 16.561 & $.000^{* * *}$ \\
\hline & $\begin{array}{l}\text { Communication } \\
\text { knowledge }\end{array}$ & .776 & .043 & .742 & 18.212 & $.000^{* * *}$ \\
\hline & $\begin{array}{l}\text { Communication } \\
\text { skills }\end{array}$ & .782 & .043 & .745 & 18.326 & $.000^{* * *}$ \\
\hline & $\begin{array}{l}\text { Self-emotional } \\
\text { appraisal }\end{array}$ & .563 & .041 & .645 & 13.885 & $.000^{* * *}$ \\
\hline & $\begin{array}{c}\text { Emotional } \\
\text { appraisal of others }\end{array}$ & .543 & .043 & .607 & 12.552 & $.000^{* * *}$ \\
\hline & Use of emotions & .672 & .038 & .732 & 17.651 & $.000^{* * *}$ \\
\hline & $\begin{array}{l}\text { Emotional } \\
\text { regulation }\end{array}$ & .517 & .040 & .621 & 13.009 & $.000^{* * *}$ \\
\hline
\end{tabular}

${ }^{* * *} \mathrm{p}<.001$.

Table 3. Hierarchical regression analysis.

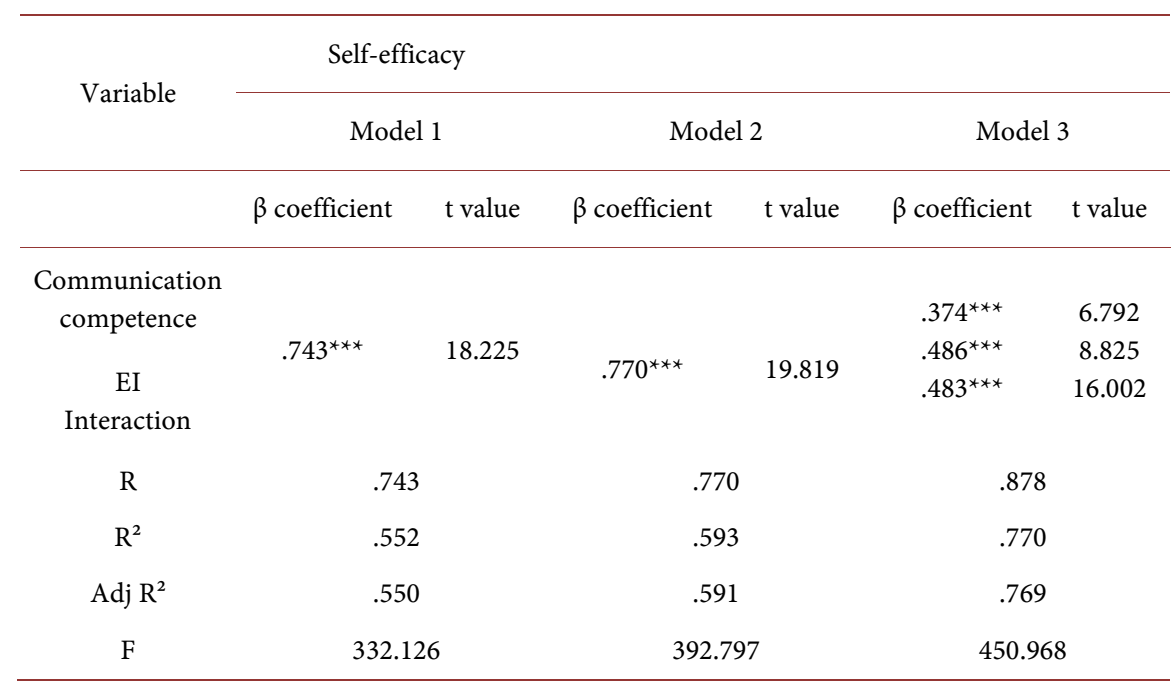

${ }^{* * *} \mathrm{p}<.001$

the lowest effect, meaning that better communication skills were associated with higher overall self-efficacy. Payne (2005) stated that communication skills are 
the most difficult element in interpersonal communication. Participants in this study had the lowest average scores in the communication skills construct. Better communication skills were associated with higher self-efficacy, which demonstrated that communication competence and self-efficacy complement one another in everyday life. Michael Argyle's model of social skills suggested that the most important role in communication and cognitive development belongs to various practical social skills (Harley, 1993; Hargie, Saunders, \& Sicksen, 1994). Interpersonal goals cannot be successfully achieved by only possessing communication motivation without being able to effectively use strategies to communicate a meaning during a communicative activity. As a result, self-efficacy cannot be enhanced. In sum, H1 in this study was confirmed, i.e., the communication competence of elementary school directors had a significant and positive effect on their self-efficacy.

b) Verification of the effect of ei on self-efficacy

In this study, EI was found to have a significant and positive effect on the selfefficacy of elementary school directors, meaning that better EI corresponded to higher self-efficacy. With regard to the influence of EI constructs on self-efficacy, the use of emotions had the highest effect, while others' emotional appraisal had the lowest effect. According to Bandura's (1977) theory, mastery experience, vicarious experience, verbal persuasion, and emotional arousal are important factors influencing self-efficacy. Therefore, awareness of one's physiological state and emotional changes, appropriate regulation and control over them, and the perception of subtle emotional changes in others can improve one's professionalism and performance, thus increasing self-efficacy. According to Salovey and Mayer (1997), EI involves the ability to promote thinking through emotions. Those who are better able to use their emotions can motivate themselves when faced with predicaments and setbacks and turn negative emotions into the power to do one's best at everything, thus promoting self-efficacy. In sum, $\mathrm{H} 2$ in this study was confirmed, i.e., the EI of elementary school directors had a significant and positive effect on their self-efficacy.

c) Verification of the moderating effect of ei on the relationship between communication competence and self-efficacy

The third research objective in this study was to examine the moderating effect of EI on the relationship between communication competence and self-efficacy. EI was found to have a significant moderating effect on the relationship between communication competence and self-efficacy in elementary school directors. In other words, EI could strengthen or weaken the influence of communication competence on self-efficacy. A literature review showed that EI, also referred to as non-academic intelligence, non-cognitive intelligence, and non-intelligence, involves such important components as Thorndike's (1920) social intelligence, Garner's (1983) interpersonal intelligence, and Sternberg's (1985) success intelligence. Being able to enrich self-efficacy by gaining knowledge through practice, EI can regulate the relationship between communication competence and self-efficacy. Furthermore, Goleman (1995) pointed out that EI 
involves appropriate emotion management, which allows one to develop a proper reaction or strategy in different communication situations and achieve personal goals. This study verified that EI has a moderating effect on the relationship between communication competence and self-efficacy. In sum, H3 was confirmed in this study, i.e., EI was found to have a moderating effect on the relationship between communication competence and self-efficacy.

\section{Conclusions and Suggestions}

\subsection{Conclusions}

1) The communication competence of Kaohsiung elementary school directors had a significant effect on their self-efficacy.

The influence of communication competence and its constructs on self-efficacy reached a significant level represented by a positive value, meaning that school directors' communication competence had a significant effect on their self-efficacy. The strongest influence was exerted by communication skills, followed by communication knowledge. The weakest influence was exerted by communication motivation.

2) The EI of Kaohsiung elementary school directors had a significant effect on their self-efficacy.

The influence of EI and its constructs on self-efficacy reached a significant level represented by a positive value, meaning that school directors' EI had a significant effect on their self-efficacy. The strongest influence was exerted by the use of emotions, followed by self-emotional appraisal and emotional regulation. The weakest influence was exerted by others' emotional appraisal.

3) The EI of Kaohsiung elementary school directors had a moderating effect on the relationship between communication competence and self-efficacy.

The moderating effect of EI on the relationship between communication competence and self-efficacy reached a significant level, meaning that depending on school directors' EI performance, their communication competence affects self-efficacy in different directions and to different extents.

\subsection{Suggestions}

Educational administrative bodies should establish special departments of communication or invite instructors specializing in inter-personal communication to guide students on how to adapt to diverse inter-personal interaction relationships within the campus. The authorities should develop advanced studies in communication competence and emotional literacy courses for new school directors. Workshops with active training aimed at improving communication competence should be organized for directors with lower levels of communication competence in order to provide immediate results.

Schools should face the importance of non-formal communication and provide their members with more time and space for a friendly and convenient communication environment. Furthermore, schools can evaluate their authoritative resources, such as reward power and coercive power, which can be used to 
assist directors in achieving their goals. Schools can increase the efficiency of directors' communication by determining who uses which resources and which resources would be most beneficial in achieving goals. Special and annual meetings should be organized to address various issues and discuss strategies to solve administrative and academic issues. School principals can frequently discuss their experiences with directors and help them when necessary in order to build a friendly school team.

Elementary school directors should develop their inter-personal relationships, learn through the experience of interacting with strangers, master a successful model of inter-personal communication, and use their communication experience in school affairs. Similar to teachers, school directors should possess empathy and be able to sympathize. By maintaining attentiveness and peacefulness in communication with others, directors can further regulate their behavior and produce appropriate responses, enabling the smooth management of school affairs and developing confidence and a sense of achievement at the workplace

\section{References}

Abdolvahabi, Z., Bagheri, S., \& Kioumarsi, F. (2012). Relationship between Emotional Intelligence and Self-Efficacy in Research among Tehran Physical Education Teachers. European Journal of Experimental Biology, 2, 2337-2343.

Ashton, P. (1984). Teacher Efficacy: A Motivational Paradigm for Effective Teacher Education. Journal of Teacher Education, 35, 287-232. https://doi.org/10.1177/002248718403500507

Austin, J. L. (1962). How to Do Things with Words. Oxford: Oxford University Express.

Bandura, A. (1977). Self-Efficacy: Toward a Unifying Theory of Behavior Change. Psychological Review, 84, 191-215. https://doi.org/10.1037/0033-295X.84.2.191

Bandura, A. (1986). Social Foundations of Thought and Action: A Social Cognitive Theory. Englewood Cliffs, NJ: Prentice-Hall.

Bandura, A. (1993). Perceived Self-Efficacy in Cognitive Development and Functioning. Educational Psychologist, 28, 117-148. https://doi.org/10.1207/s15326985ep2802_3

Bandura, A. (1997). Self-Efficacy: The Exercise of Control. New York: W. H. Freeman.

Bar-on, R. (1997). The Emotional Intelligence Inventory (EQ-i): Technical Manual. Toronto: Multi-Health Systems.

Boroon, R. (2013). Evaluation of the Managers' Communication Skills baseD on Systematic Approach in Petroleum Welfare Services Company. European Online Journal of Natural and Social Sciences, 2, 1689-1695.

http://european-science.com/eojnss/article/view/833

Carnegie, D. (1936). How to Win Friends and Influence People. New York: Simon and Schuster.

Engelberg, E., \& Sjobery, L. (2005). Emotional Intelligence and Inter-Personal Skills. In R. Schulze, \& R. D. Roberts (Eds.), Emotional Intelligence: An International Handbook (pp. 289-305). Cambridge, MA: Hogrefe \& Huber.

Goddard, R. D., Hoy, W. K., \& Woolfolk, A. (2000). Collective Teacher Efficacy: Its Meaning, Measure, and Effect on Student Achievement. American Education Research Journal, 37, 479-507. https://doi.org/10.3102/00028312037002479

Goleman, D. (1995). Emotional Intelligence. New York: Bantam. 
Goleman, D. (1998). Working with Emotional Intelligence. New York: Bantam.

Grice, H. P. (1975). Logic and Conversation. In P. Cole, \& J. Morgan (Eds.), Syntax and Semantics, Vol. 3, Speech Acts (pp. 41-58). New York: Academic Press.

Hannah, S. T., Avolio, B. J., Luthans, F., \& Harms, P. D. (2008). Leadership Efficacy: Review and Future Directions. The Leadership Quarterly, 19, 669-692.

Hargie, O., Saunders, C., \& Sickson, D. (1994). Social Skills in Interpersonal Communication. New York: Routledge.

Harley, P. (1993). Interpersonal Communication. New York: Routledge.

Jorfi, H., Jorfi, S., Yacoob, H. F. B., \& Nor, K. M. (2014). The Impact of Emotional Intelligence on Communication Effectiveness: Focus on Strategic Alignment. African Journal of Marketing Management, 6, 82-87.

Lazarus, R. S., \& Folkman, S. (1984). Stress, Appraisal, and Coping. New York: Springer.

Mandler, G. (1980). The Generation of Emotion: A Psychological Theory. In R. Plutchik, \& H. Kellerman (Eds.), Theories of Emotion. New York: Academic Press.

Marzuki, N. A., Mua, C. S., \& Saad, Z. M. (2015). Emotional Intelligence: Its Relationship with Communication and Information Technology Skills. Asian Social Science, 11, 267-274.

Mayer, J. D., Salovey, P., \& Caruso, D. R. (2002). The Mayer-Salovey-Caruso Emotional Intelligence Test (MSCEIT), Version 2.0. Toronto: Multi Health Systems.

McCormick, M. J., Tanguma, J., \& Lopez-Forment, A. S. (2002). Extending Self-Efficacy to Leadership: A Review and Empirical Test. Journal of Leadership Education, 1, 34-49.

Mead, G. H. (1934). Mind, Self, and Society. Chicago, IL: University of Chicago.

Moradi-Dasht, S., \& Noorbakhsh, M. (2014). The Relationship between Emotional Intelligence and Communication Skills in International Table Tennis Female Coaches. European Journal of Zoological Research, 3, 97-101. http://scholarsresearchlibrary.com/ejzr-vol3-iss1/EJZR-2014-3-1-97-101.pdf

Nikoopour, J., Farsani, M. A., Tajbakhsh, M., \& Kiyaie, S. H. S. (2012). The Relationship between Trait Emotional Intelligence and Self-Efficacy among Iranian EFL Teachers. Journal of Language Teaching and Research, 3, 1165-1174. https://doi.org/10.4304/jltr.3.6.1165-1174

Payne, H. J. (2005). Reconceptualizing Social Skills in Organizations: Exploring the Relationship between Communication Competence, Job Performance and Supervisory Roles. Journal of Leadership and Organizational Studies, 11, 63-77. https://doi.org/10.1177/107179190501100207

Petrides, K. V., \& Furnham, A. (2000). On the Dimensional Structure of Emotional Intelligence. Personality and Individual Differences, 29, 313-320.

Pont, B., Nusche, D., \& Moorman, H. (Eds.) (2008). Improving School Leadership Volume 1: Policy and Practice. Paris: OECD.

Potter, J., \& Edwards, D (2001). Discursive Social Psychology. In W. P. Robinson, \& H. Giles (Eds.), The New Handbook of Language and Social Psychology (pp. 103-118). New York: Wiley.

Salovey, P., \& Mayer, J. D. (1990). Emotional Intelligence. Imagination, Cognition, and Personality, 9, 185-211. https://doi.org/10.2190/DUGG-P24E-52WK-6CDG

Salovey, P., \& Mayer, J. D. (1997). What Is Emotional Intelligence? In P. Salovey, \& D. Sluyter (Eds.), Emotional Development and Emotional Intelligence: Implications for Educators (pp. 3-31). New York: Basic Books.

Sarkhosh, M., \& Rezaee, A. A. (2014). How Does University Teachers' Emotional Intelligence Relate to Their Self-Efficacy Beliefs? Porta Linguarum, 21, 85-100. 
Schramm, W. (1971). The Nature of Communication between Humans. In W. Schramm, \& D. F. Roberts (Eds.), The Process and Effects of Mass Communication (pp. 3-516). Urbana, IL: University of Illinois Press.

Semin, G. R. (n.d.). Language and Social Cognition. In F. Strack, \& J. Forster (Eds.), Social Cognition-The Basis of Human Interaction. New York: Psychology Press.

Silverman, S. K., \& Davis, H. A. (2009). Teacher Efficacy. In E. Anderman, \& L. Anderman (Eds.), Psychology of Classroom Learning: An Encyclopedia (PCL) (Vol. 2, pp. 915-920). New York: Macmillan Reference.

Spitzberg, B. H., \& Cupach, W. R. (1984). Interpersonal Communication Competence. Beverly Hills, CA: Sage.

Spitzberg, B. H., \& Cupach, W. R. (1989). Handbook of Interpersonal Competence Research. New York: Springer-Verlag. https://doi.org/10.1007/978-1-4612-3572-9

Stearns, P. N., \& Stearns, D. C. (1994). Biology and Culture: Toward a New Combination. Contention, 3, 29-53.

Tariszka-Semegine, E. (n.d.). Organizational Internal Communication as a Means of Improving Efficiency. European Scientific Journal, 8, 86-96.

Tschannen-Moran, M., \& Gareis, C. R. (2004). Principals' Sense of Efficacy. Journal of Educational Administration, 42, 573-585. https://doi.org/10.1108/09578230410554070

Tschannen-Moran, M., \& Woolfolk-Hoy, A. (2001). Teacher-Efficacy: Capturing an Elusive Construct. Teaching and Teacher Education, 17, 783-805.

Vygotsky, L. S., Edited by Cole, M., John-Steiner, V., Scribner, S. and Souberman, E. (1978). Mind in Society. Cambridge, MA: Harvard University Press.

Wong, C. S., \& Law, K. S. (2002). The Effects of Leader and Follower Emotional Intelligence on Performance and Attitude: An Exploratory Study. The Leadership Quarterly, 13, 243-274.

Submit or recommend next manuscript to SCIRP and we will provide best service for you:

Accepting pre-submission inquiries through Email, Facebook, LinkedIn, Twitter, etc. A wide selection of journals (inclusive of 9 subjects, more than 200 journals)

Providing 24-hour high-quality service

User-friendly online submission system

Fair and swift peer-review system

Efficient typesetting and proofreading procedure

Display of the result of downloads and visits, as well as the number of cited articles

Maximum dissemination of your research work

Submit your manuscript at: http://papersubmission.scirp.org/

Or contact ce@scirp.org 